\title{
Review on lipegfilgrastim
}

\section{Maja Gasparic \\ Sophie Leyman}

Teva Pharmaceuticals Europe BV, European Headquarters, Amsterdam, the Netherlands
Correspondence: Maja Gasparic Teva Pharmaceuticals Europe BV, European Headquarters, Piet Heinkade 107, 1019 GM Amsterdam, the Netherlands Email maja.gasparic@pliva.com
This article was published in the following Dove Press journal:

International Journal of Nanomedicine

3 November 2015

Number of times this article has been viewed

\section{Dear editor}

Having read the original Hoggatt et al article ${ }^{1}$ and the corrigendum published online on August 27, 2015, ${ }^{2}$ we do not consider the description of lipegfilgrastim to be entirely accurate, and we would therefore like to clarify what lipegfilgrastim actually is.

The description of lipegfilgrastim used in the original article was a "long-acting biosimilar filgrastim". ${ }^{1}$ This description was subsequently amended in the corrigendum to "lipegfilgrastim has an active substance that is similar to filgrastim, with similar pharmacokinetics, receptor binding affinity, safety and efficacy as pegfilgrastim". ${ }^{2}$

It is true that lipegfilgrastim is not a long-acting biosimilar of filgrastim. It is not approved under the biosimilar classification by the European Medicines Agency, and has its own distinct Anatomical Therapeutic Chemical (ATC) code (ATC code L03AA14, lipegfilgrastim; ATC code L03AA02, filgrastim; ATC code L03AA13, pegfilgrastim). ${ }^{3}$ Further, we believe lipegfilgrastim would be more accurately described as "glycopegylated, long-acting form of recombinant human filgrastim".

Furthermore, the original article does not give the correct indications for either filgrastim or lipegfilgrastim (eg, pages 2,648 and 2,649). ${ }^{1}$ In August 2013, the European Medicines Agency (EMA) approved lipegfilgrastim to be used for reducing the duration of neutropenia and the incidence of febrile neutropenia in adult patients treated with cytotoxic chemotherapy for malignancy (with the exception of chronic myeloid leukemia and myelodysplastic syndromes) ${ }^{4}$ Lipegfilgrastim is currently marketed throughout Europe with this indication.

\section{Disclosure}

Both authors are employees of Teva Pharmaceuticals Europe BV. The authors report no other conflicts of interest in this communication.

\section{References}

1. Hoggatt J, Tate TA, Pelus LM. Role of lipegfilgrastim in the management of chemotherapy-induced neutropenia. Int J Nanomedicine. 2015;10:2647-2652.

2. Hoggatt J, Tate TA, Pelus LM. Role of lipegfilgrastim in the management of chemotherapy-induced neutropenia [corrigendum]. Int J Nanomedicine. 2015;10:5421.

3. European Commission [webpage on the Internet]. Full human ATC code list. European Commission; 2015. Available from: $h t t p: / / e c . e u r o p a . e u / h e a l t h /$ documents/community-register/html/atc.htm. Accessed 15 September 2015

4. Electronic Medicines Compendium (eMC) [webpage on the Internet]. Lonquex ${ }^{\circledR}$ : summary of product characteristics. Electronic Medicines Compendium (eMC); 2015. Available from: https://www.medicines. org.uk/emc/medicine/28948. Accessed 15 September 2015. 
Dove Medical Press encourages responsible, free and frank academic debate. The content of the International Journal of Nanomedicine 'letters to the editor' section does not necessarily represent the views of Dove Medical Press, its officers, agents, employees, related entities or the International Journal of Nanomedicine editors. While all reasonable steps have been taken to confirm the content of each letter, Dove Medical Press accepts no liability in respect of the content of any letter, nor is it responsible for the content and accuracy of any letter to the editor.

International Journal of Nanomedicine

Dovepress

\section{Publish your work in this journal}

The International Journal of Nanomedicine is an international, peerreviewed journal focusing on the application of nanotechnology in diagnostics, therapeutics, and drug delivery systems throughout the biomedical field. This journal is indexed on PubMed Central, MedLine, CAS, SciSearch ${ }^{\circledR}$, Current Contents $₫ /$ Clinical Medicine,

Journal Citation Reports/Science Edition, EMBase, Scopus and the Elsevier Bibliographic databases. The manuscript management system is completely online and includes a very quick and fair peer-review system, which is all easy to use. Visit http://www.dovepress.com/ testimonials.php to read real quotes from published authors.

Submit your manuscript here: http://www.dovepress.com/international-journal-of-nanomedicine-journal 